Rechtsmedizin 2007 · 17:40-43 DOI 10.1007/s00194-006-0425-8

Online publiziert: 12. Januar 2007

๑) Springer Medizin Verlag 2007
Virtopsy Team $^{1,2} \cdot$ L. Oesterhelweg $^{1}$

${ }^{1}$ Zentrum für Forensische Bildgebung/Virtopsy, Institut

für Rechtsmedizin, Universität Bern, Bern

${ }^{2}$ Institut für Diagnostische, Interventionelle und

Pädiatrische Radiologie, Inselspital, Bern

\title{
Atmosphere of departure in forensic medicine?
}

\author{
Virtopsy Basic Course
}

Regarding autopsies, imaging procedures like $\mathrm{x}$-ray and surface scanning are methods in their childhood in forensic science but are becoming more and more a valuable tool in institutes of legal medicine in Europe, America and Asia. Byron G. Brogdon gave a vivid statement in his book Forensic Radiology: „The sad truth is that a century after the first $\mathrm{x}$-ray was introduced as evidence in a law court, there is no general appreciation of the extent of the radiology potential in the forensic sciences"[1]. This statement published in 1998 was one of the triggers for research projects like the Virtopsy project in Bern. Since 1998 many scientific publications on the use of computed tomography, magnetic resonance imaging, surface scanning and $3 \mathrm{D}$ reconstruction have been published by various working groups $[1,2,3,4,5,6,7,8]$. These few groups established the mentioned procedures as routine tools in their daily forensic work. The question of education in this special interdisciplinary field of forensic sciences was becoming more apparent which led to the first Virtopsy basic course in Bern, Switzerland.

\section{Virtopsy basic course}

In September 2006 participants from Austria, Germany, Italy, Japan, Switzerland, Turkey and the USA met in Bern for the first Virtopsy basic course ( $\bullet$ Fig. 1). This course was designed as a hands-on work- shop, using surface scanning, CT-scanning and CT-workstation reconstruction and was held by forensic pathologists, radiologists and measurement engineers. In addition to the practical work, the theoretical background was presented in lectures.

Surface scanning. In a demonstration by the measurement engineers the participants were introduced to the technique of photogrammetry and ${ }_{3} \mathrm{D}$ surface scanning of different tools - possible instruments in forensic cases. The components of the procedures - the digital measurement camera (Nikon D2X, Nikon AG, Switzerland) and the surface scanner (GOM Atos II, Gesellschaft für optische Messtechnik $\mathrm{mbH}$, Deutschland; - Fig. 2) were explained. In the practical part, melons $(\mathrm{Cu}-$ cumis melo) were "maltreated“ by the participants with different instruments knife, hammer, airgun, etc. - leaving im- printed traces on the surface of the melon (- Fig. 3). After these procedures the melons were prepared with reference markers for the surface scans and a complete surface documentation was performed by the participants ( $\bullet$ Fig. 4).

CT-scanning. After an overview on the development and the technique of computed tomography, a demonstration of multislice computed tomography (Siemens Somatom Emotion 6, Siemens Medical Solutions, Germany) by the Institute of Forensic Medicine, Bern was given on a scan of a corpse that was transferred to the Institute of Forensic Medicine for radiological documentation and autopsy (• Fig. 5). The participants were able to perform adjustments of the scan. In a second practical part the participants used the abovementioned melon model to scan by themselves.
Fig. 1 Participants of the first Virtopsy basic course and the Virtopsy team. (Teilnehmer und Team des ersten VirtopsyGrundkurses)

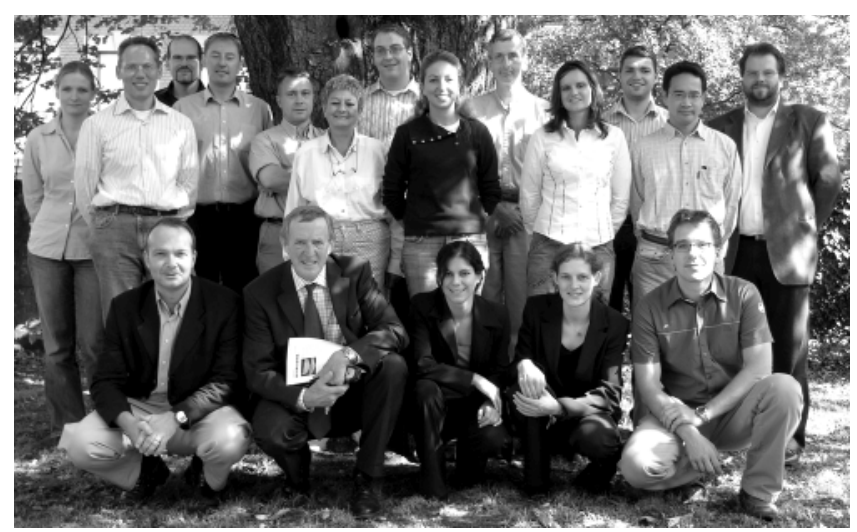


2D and 3D data reconstruction. One of the most important parts is the documentation of cases and the reconstruction of data in 2 and 3 dimensions. Therefore the workstation (Siemens Leonardo, Siemens Medical Solutions, Germany) and applications for adjustment of the 2-dimensional images and the 3-dimensional virtual models were presented using the data of the scanned corpse ( $\bullet$ Fig. 6 ). In the practical part the participants had to reconstruct the injuries on the melon produced by the maltreatment and got to know the reconstructions of gunshot channels and stab wounds (• Fig. 7). Also a basic overview of the data storage possibilities and the software solutions was given.

\section{Conclusions}

The resonance of the first Virtopsy basic course was highly positive and the demand for a Virtopsy advanced course was voiced. This seemed to be a basis for an extension of imaging techniques to forensic sciences and will hopefully be a platform for scientific research projects and knowledge exchange.

\section{Corresponding author}

\section{Dr. L. Oesterhelweg}

Zentrum für Forensische Bildgebung/Virtopsy, Institut für Rechtsmedizin, Universität Bern Bühlstrasse 20, CH-3012 Bern

lars.oesterhelweg@irm.unibe.ch

Conflict of interest. There is no conflict of interest. The corresponding author affirms that he/she has no connection with any company whose product is mentioned in this article or any company that markets a competing product. The presentation of the findings is free of bias and product-neutral.

Acknowledgement. The Virtopsy team gratefully acknowledge the support of the first Virtopsy basic course by Siemens Medical Solutions, Germany; GOM International AG, Switzerland; Sectra, Linköping, Sweden and the Virtopsy Foundation.

Rechtsmedizin 2007 · 17:40-43 DOI 10.1007/s00194-006-0425-8

(C) Springer Medizin Verlag 2007

Virtopsy Team · L. Oesterhelweg Aufbruchstimmung in der Rechtsmedizin? Virtopsy Basic Course

\section{Zusammenfassung}

Kernaufgaben der Rechtsmedizin sind die Erhebung und die Dokumentation forensisch relevanter Befunde an Lebenden und Toten für die Ermittlungsorgane und die Justiz. Während in den Arbeitsbereichen der forensischen Molekularbiologie und der forensischen Toxikologie bereits „High-tech-Verfahren" den täglichen Arbeitsablauf dominieren, bedient sich die forensische Pathologie nach wie vor der Jahrhunderte alten Sektionstechniken und des Befundprotokolls. Moderne Dokumentationsverfahren wie Oberflächen-Scanning und radiologische Schnittbildverfahren wie Computertomographie (CT) und "magnetic resonance imaging" (MRI) stehen mehr und mehr im Fokus der foren-

sischen Wissenschaften und finden zunehmend Eingang in die Routinemethoden einzelner Institute. Als Zeichen des steigenden Interesses an diesen Verfahren fand im September 2006 der erste „Virtopsy basic course“ im Zentrum für forensische Bildgebung/Virtopsy im Institut für Rechtsmedizin der Universität Bern statt. Teilnehmer aus Deutschland, Italien, Japan, Österreich, der Schweiz, der Türkei und den USA nahmen an diesem ersten Workshop in forensischer Radiologie und Oberflächendokumentation teil.

\section{Schlüsselwörter}

Forensische Radiologie · Oberflächendokumentation - Virtopsy

\section{Atmosphere of departure in forensic medicine? Virtopsy Basic Course}

\section{Abstract}

Forensic medicine aims for the documentation of medical and other forensic findings in living and deceased persons for the police and the judiciary system. While in forensic genetics and forensic toxicology, high technology procedures are part of the daily work, forensic pathology is still using the old established techniques from former centuries. New methods like 3D-surface scanning and modern radiology procedures like computed tomography (CT) or magnetic resonance imaging (MRI) are becoming more and more part of scientific research in forensic sciences and are today part of the routine workflow in a some institutes of legal medicine. As a sign of this increasing interest the first Virtopsy basic course was held in September 2006 at the Center for Forensic Imaging/Virtopsy in the Institute of Forensic Medicine in Bern, Switzerland. Participants from Austria, Germany, Italy, Japan, Switzerland, Turkey and the USA took part in this first hands-on course in forensic radiology and surface scanning.

\section{Keywords}

Forensic radiology · Surface scanning . Virtopsy 


\section{Leitthema}

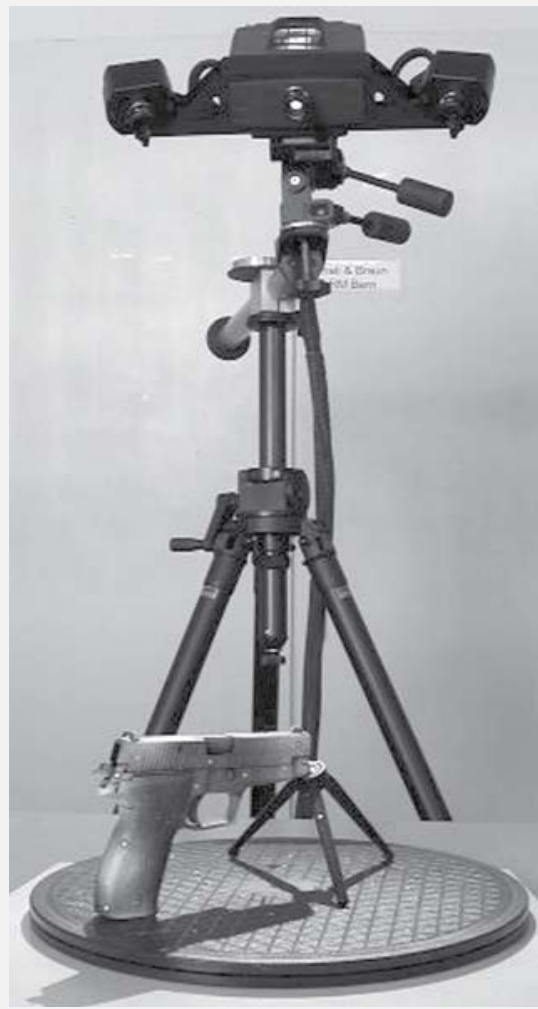

Fig. $2 \Delta$ GOM Atos II surface scanner. (GOM Atos II Oberflächen-Scanner)

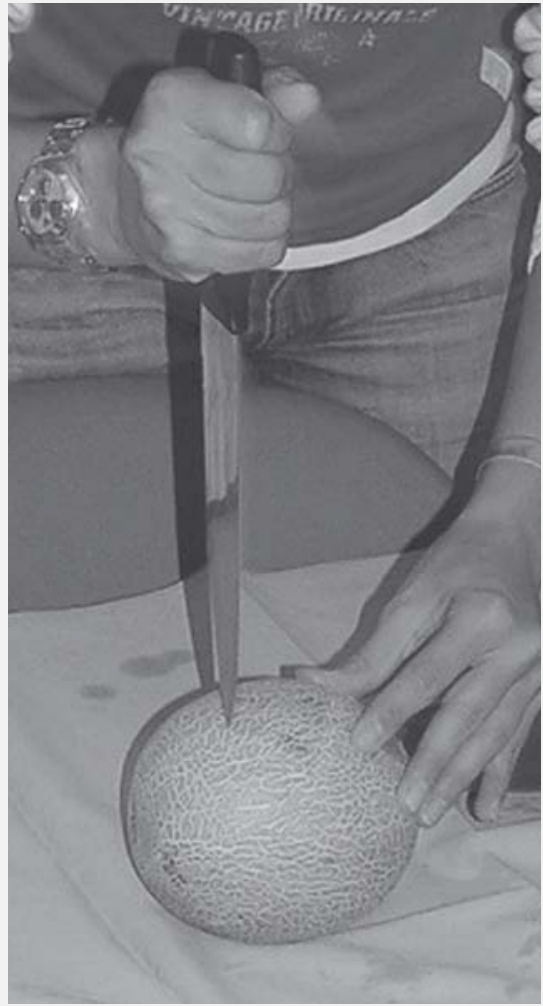

Fig. $3 \Delta$ Maltreatment of melons. („Misshandlung" von Melonen)

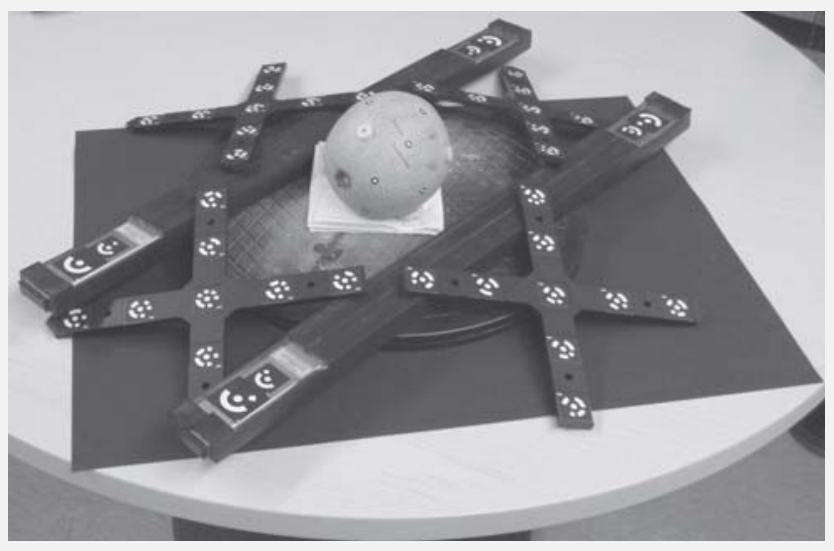

Fig. $4 \varangle$ Surface scanning objects. (OberflächenScanning-Objekte)

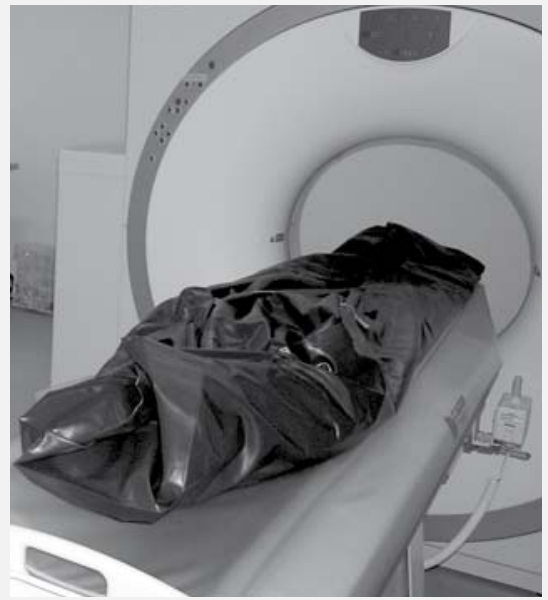

Fig. $5 \Delta$ Postmortem CT-scan of a corpse in a body bag. (Siemens Emotion 6; postmortale Computertomographie einer Leiche in einem Leichensack)

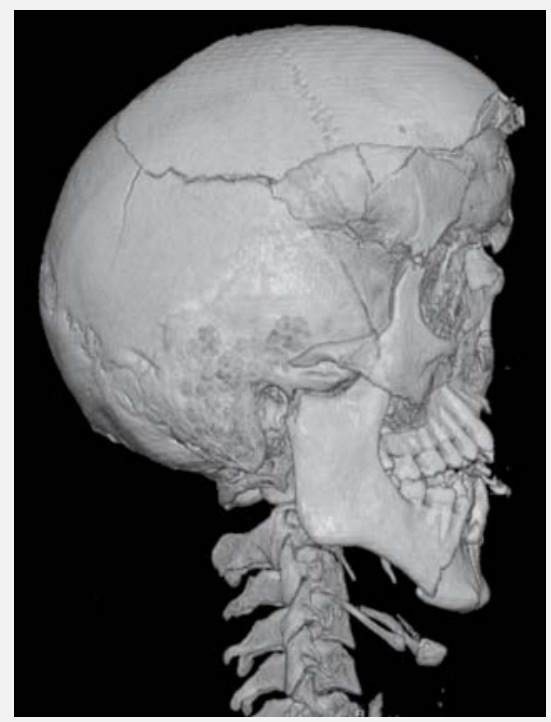

Fig. $6 \Delta 3 D$ reconstruction of a skull with facial fractures after a fall from a bridge. (3D-Rekonstruktion eines Schädels mit Gesichtsfrakturen nach Sturz von einer Brücke)

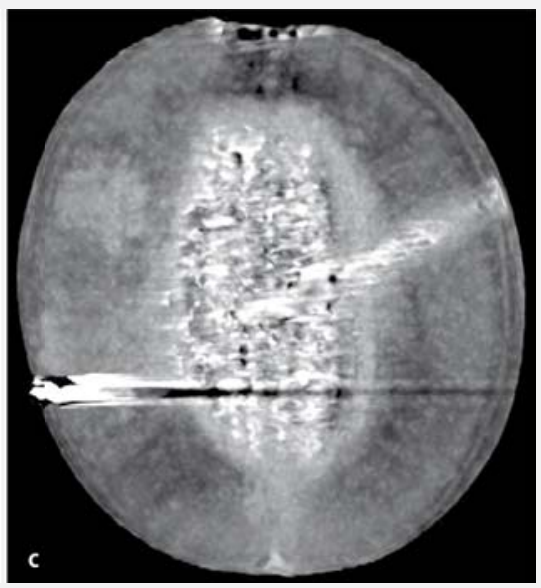

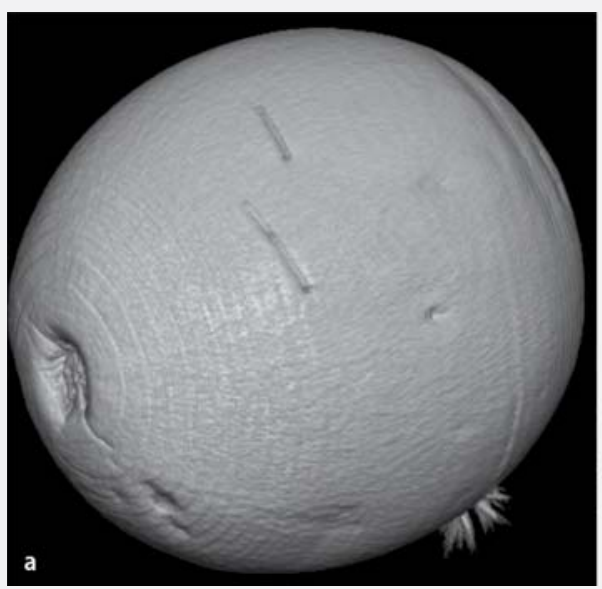

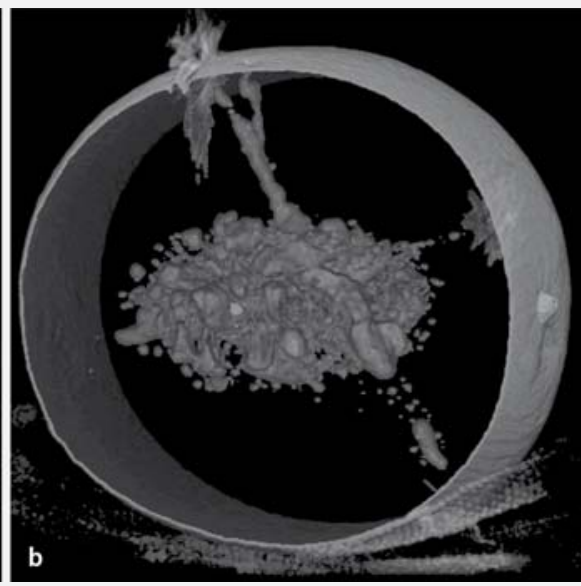

Fig. $7 \Delta$ Documentation of the damages to a melon by CT (Dokumentation der "Verletzungen" einer Melone mithilfe der Computertomographie) 


\section{Buchbesprechung}

\section{References}

1. BrogdonBG(1998)Forensicradiology.CRC,BocaRaton

2. Dirnhofer R, Jackowski C, Vock P et al. (2006) Virtopsy: minimally invasive. Imaging-guided virtual autopsy. Radiographics 26: 1305-1333

3. Myers JC, Okoye MI, Kiple D et al. (1999) Threedimensional (3-D) imaging in post-mortem examinations: elucidation and identification of cranial and facial fractures in victims of homicide utilizing 3-D computerized imaging reconstruction techniques. Int J Legal Med 113: 33-37

4. Paperno S, Riepert T, Krug B et al. (2005) Prospektive Untersuchung zur Wertigkeit der postmortalen Computertomographie im Vergleich zur Autopsie. Rofo 177: 130-136

5. Poulsen K, Simonsen J (2006) Computed tomography as routine in connection with medico-legal autopsies. Forensic Sci Int (in press)

6. Stein KM, Bahner ML, Merkel J et al. (2000) Detection of gunshot residues in routine CTs. Int J Legal Med 114: 15-18

7. Thali MJ, Braun M, Dirnhofer R (2003) Optical 3D surface digitizing in forensic medicine: 3D documentation of skin and bone injuries. Forensic Sci Int 137: 203-208

8. Thali MJ, Yen K, Schweitzer W et al. (2003) Virtopsy, a new imaging horizon in forensic pathology: virtual autopsy by postmortem multislice computed tomography (MSCT) and magnetic resonance imaging (MRI) - a feasibility study. J Forensic Sci 48: 1-18
Thiemann, H.-H., I. Nitz, A. Schmeling

(Hrsg.)

Röntgenatlas der normalen Hand im Kindesalter

Stuttgart: Georg Thieme Verlag 2006,

149 S., 148 Abb., 74 Tab.,

(ISBN 3-13-766603-1), 89.00 EUR

Der "Thiemann-Nitz" gehört seit Jahren zu den wichtigsten - leider nicht überall be-

kannten - Standardwerken über die normale Ossifikation der menschlichen Hand. Anfänglich war die Erkennung von Wachstumsstörungen das Hauptanwendungsgebiet, später die Errechnung der vermutlichen Endgröße von Kindern einschließlich eventueller therapeutischer Maßnahmen. Schließlich kam in letzter Zeit die Bedeutung für die forensische Altersdiagnostik hinzu. Dem wurde die 3. Auflage durch Hinzuziehung von forensischen Experten der Altersschätzung gerecht.

Der Textteil gliedert sich in eine kurze „Einführung", den Abschnitt "Methodik" zur Durchführung und Auswertung der Röntgenaufnahmen, das Kapitel „Allgemeine Befunde“ mit Erläuterung der Knochenentwicklung, das Kapitel „Berechnung der zu erwartenden Endgröße" nach den Methoden von Bayley und Pinneau sowie von Roche, Wainer und Thissen, jeweils mit den entsprechenden Tabellen. Den Textteil beschließt das kurze Kapitel „Forensische Altersdiagnostik im Strafverfahren".

Den Hauptteil machen die Bildtafeln aus. Sie sind sehr übersichtlich angeordnet, getrennt nach Geschlecht und Altersgruppen (für das Neugeborenenalter in Vierteljahresschritten, für das Kindesalter in Halbjahresschritten, und für Jugendliche in Jahresabständen). Während der Buchtitel nur das Kindesalter berücksichtigt, umfasst das Bildmaterial auch das Jugendalter (bis zu 18 Jahren). Zu jedem Fall gibt es eine Röntgenaufnahme, ein erläuterndes Schema sowie eine Tabelle mit den Abmessungen der Handknochen der entsprechenden Altersgruppe unter Angabe von Mittelwerten und Standardabweichungen. Diese Einfügung der Streubreiten stellt eine wichtige Neuerung dar. Die Qualität der Abbildungen ist tadellos, gleiches gilt für die gesamte Aufmachung des Buches.
Die Aktualisierung und Erweiterung des Röntgenatlas ist ausdrücklich zu begrüßen und wird seiner weiteren Verbreitung dienen. Das Buch wird speziell für Genetiker, Orthopäden, Pädiater, Radiologen und Rechtsmediziner eine wichtige Hilfe sein.

G. Geserick (Berlin) 